\title{
Strength of Concrete using Clay as a Partial Replacement of Binder Content with and Without Lime
}

\author{
Sachin B. Kandekar, Swati K. Wakchaure
}

\begin{abstract}
Materials are the most important component of building construction. The demands of construction material are increasing day by day significantly. This demand is increasing the material prices and scarcity of material in construction industry. To achieve economical and eco-friendly criteria naturally occurring material is selected. Clay is a natural material and it can be available easily. This paper interprets the experimental investigation on strength of concrete using clay as a partial replacement to binder content (cement) in concrete. The replacement percentages are grouped as $0 \%, 10 \%, 20 \%, 30 \%$, $40 \%$ of clay and $5 \%$ of hydrated lime with cement in each series in M25 grade of concrete. To achieve the pozzolanic property of clay hydrated lime was added. Different tests are performed to determine the optimum percentage of clay as a replacement for binder content (cement) in concrete. The Compressive strength test, split tensile strength test and flexural strength test were performed on the specimens. Total 90 cubes of size $150 \mathrm{~mm}$ were prepared for compressive strength test, 30 cylinders of $150 \mathrm{~mm}$ diameter and $300 \mathrm{~mm}$ height were prepared for split tensile strength test and 30 beams of size $150 \mathrm{~mm} \times 150 \mathrm{~mm} \times 1000 \mathrm{~mm}$ were prepared to carry out the flexural strength test. The results are compared to find the ideal proportion of clay as a replacement for cement. It is found that $10 \%$ replacement with $5 \%$ hydrated lime gives satisfactory results.
\end{abstract}

Keywords: Clay, Concrete, Hydrated lime, Partial replacement, Pozzolanic property, Replacement percentage.

\section{INTRODUCTION} provides good strength, durability, impermeability, resistance to fire and abrasion, etc. Cement is the main component for making concrete. The environmental degradation took place by the use of various materials in the building construction. These materials are cement, sand, bricks, steel, wood, glass, tiles, etc. Sometimes harmful pollutants are released by building materials damaging the environment [1]. In the production of cement, there is a large magnitude of creation of $\mathrm{CO} 2$ gas which is hazardous to our environment [2].

Manuscript received on July 16, 2021.

Revised Manuscript received on August 20, 2021.

Manuscript published on September 30, 2021.

* Correspondence Author

S. B. Kandekar*, Department of Civil Engineering, Amrutvahini College of Engineering, Amrutnagar (422608) Sangamner, Savitribai Phule Pune University, Pune, India. Email: sachin.kandekar@avcoe.org

S. K. Wakchaure, Department of Civil Engineering, Amrutvahin College of Engineering, Amrutnagar (422608) Sangamner, Savitribai Phule Pune University, Pune, India. Email: swati.wak99@gmail.com

(c) The Authors. Published by Blue Eyes Intelligence Engineering and Sciences Publication (BEIESP). This is an open access article under the CC BY-NC-ND license (http://creativecommons.org/licenses/by-nc-nd/4.0/)
In construction industry concrete is used very widely. It

Today, the rise in demand for materials in building construction has resulted in significant degradation of natural resources. For this, it is beneficial to choose eco-friendly materials to achieve the structural economy. The mud concrete can be prepared by taking into account strength and durability parameters [3]. Clayey soil performs a vital role in increasing the strength and ductility of stabilized soil [4]. In some cases, calcined material is used to improve the initial and final strength of Portland cement. But it is required to find its long-term durability effect [5], [6].

Marine clay stabilization can be done by replacing cement with wood - ash. The parameters considered are unconfined compressive strength, shear modulus at the initial stage and shear strength [7]. The termite clay as a replacement to cement in roofing tile is investigated and optimum 10\% replacement in cement is found appropriate [8]. Cement can be replaced by fly ash and lime sludge (as a water softening sludge) in the preparation of mortar [9]. In some cases, Indian calcium bentonite is used as a replacement for cement [10]. The industry-produced quicklime can be used for activation of clay as a cementitious material [7]. Such replacement will decrease the production of greenhouse gases and cement production costs [11]. The construction industry is using clay as a natural abundantly available material. It is a natural pozzolana available on earth [12]. Soil efficiency can be improved using clay minerals formulating epoxy resin cement clay mixtures [4].

Clay is an economical and effective alternative for the construction of low-cost housing units. It is widely used in tropical regions where very limited resources are available [3]. Clay is used as a binder in construction for many years and still worked well. The particle size of clay is less than 2 microns which exhibits plasticity characteristics by absorbing water and shrinks after removing the water. The three main clay minerals are Kaolinite, illite, and montmorillonite. Kalins pozzolanic reactivity with calcareous montmorillonite can be used [2]. Kaolinite clay can be used as an admixture in concrete to improve strength, workability and chloride diffusion coefficient [13]. The cement paste is verified for its porosity characteristics and microstructure is assessed. The most stable clay is Kaolinite. Montmorillonite soils are quite expansive and swelling in nature whereas illite clay comes in between. An optimum dose of $20 \%$ bagasse ash with soft clay is found suitable for the replacement of Ordinary Portland Cement [14]. To activate the clay as a cementitious material, industry-produced quicklime is required [11].

Published By:

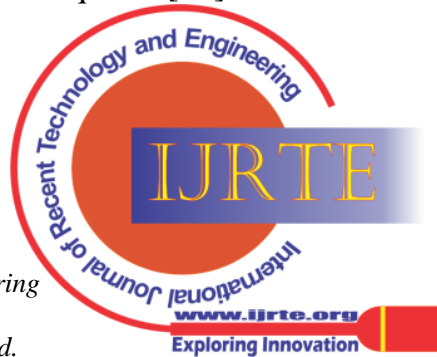


Renewable energy sources are utilized for the construction of walls. Biomass is one of the sustainable walling materials for the manufacturing of bricks [1]. Natural and synthetic fibers can be used to prepare soil blocks as an alternative to conventional bricks. [15]

Clay is an eco-friendly material and is available on-site easily. It has binding property hence; it can be used in the replacement of cement. Using a stabilizer the strength of clay can be increased. The compressive strength was taken on cubes, split tensile strength on cylinders, and flexural strength on beams. To check the strength of concrete using partial replacement of binder content (cement) with clay, it is taken in five test groups viz. $0 \%, 10 \%, 20 \%, 30 \%, 40 \%$ in two sets. The first set was without hydrated lime whereas the second set was with hydrated lime.

\section{MATERIALS AND METHODOLOGY}

The step-by-step procedure of experimental program is shown in Fig. 1. First of all, materials like cement, sand and aggregates are collected. These materials were tested in a laboratory to find their mechanical properties. The chemical formula of Calcium hydroxide is $\mathrm{Ca}(\mathrm{OH})_{2}$ acting as an organic compound. It is obtained from quicklime (calcium oxide) in the form of a colorless crystal or white powder mixing or slaking with water. Hydrated lime and quicklime are calcium compounds. Quicklime is a calcium hydroxide in a hydrated state or pure state.

The design mix is prepared for M25 grade of concrete. The concrete cubes, beams and cylinders were cast by taking sets with and without hydrated lime. The dose of hydrated lime is taken as $5 \%$ while casting specimens. The clay was added as $0 \%, 10 \%, 20 \%, 30 \%$ and $40 \%$. The curing of specimen was done for 28 days and then tested.

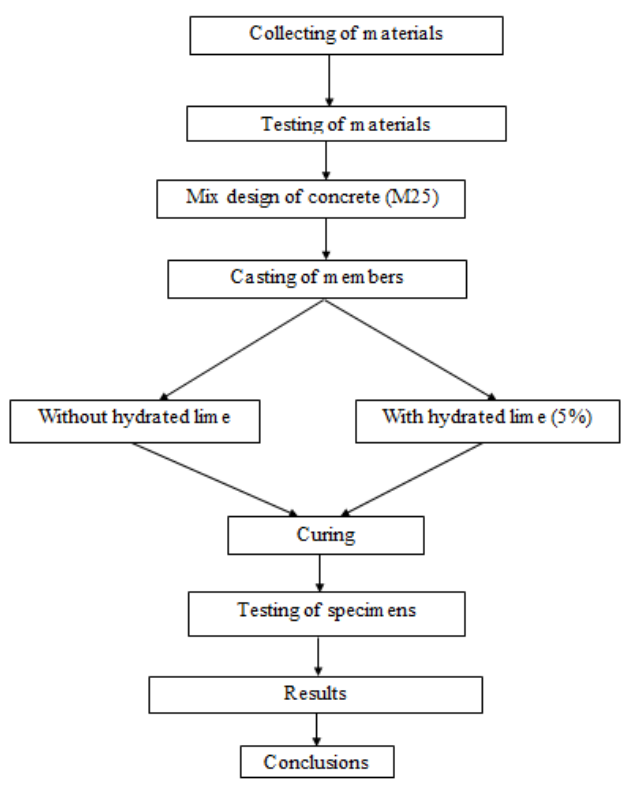

Fig. 1: Methodology

\section{A. Materials}

Materials such as cement, sand and aggregate were collected from different sources. For cement, tests like standard consistency, initial and final setting time, soundness test and compressive strength test were conducted. Sieve analysis and water absorption tests were conducted on fine aggregates as well as coarse aggregates.

Cement: - 53 grade OPC

Specific gravity: - 3.15

Fine aggregate: - natural sand from river

Specific gravity: - 2.65

Coarse aggregate: - nominal size of $20 \mathrm{~mm}$

Specific gravity: -2.74

B. Mix Proportions

Table- I: Design mix proportion (M25)

\begin{tabular}{|c|c|c|c|c|}
\hline Descriptions & Cement & $\begin{array}{c}\text { Fine } \\
\text { aggregate }\end{array}$ & $\begin{array}{c}\text { Coarse } \\
\text { aggregate }\end{array}$ & Water \\
\hline $\begin{array}{c}\text { Mix } \\
\text { proportion } \\
\text { by weight }\end{array}$ & 1 & 1.789 & 3.02 & 0.5 \\
\hline
\end{tabular}

\section{Casting procedure}

The design mix ratio of M25 was adopted as shown in Table - I for preparing specimens. A total of 90 cubes were prepared for both cases with and without hydrated lime respectively. The tests on cubes were conducted for 3 days, 7 days and 28 days. 30 cylinders and beams for both with and without hydrated lime were prepared as shown in Table - II and Fig. 2. For the case of with hydrated lime, $5 \%$ of hydrated lime with cement in each series was added. The specimens were removed from the mold after 24 hours and placed in water for curing.

Table- II: Number of specimens prepared

\begin{tabular}{|c|c|c|c|c|c|c|}
\hline \multirow[t]{2}{*}{$\begin{array}{l}\text { Sr. } \\
\text { No. }\end{array}$} & \multirow[t]{2}{*}{ Particular } & \multicolumn{3}{|c|}{ Cube } & \multirow{2}{*}{$\begin{array}{c}\text { Cylinder } \\
28 \text { Days }\end{array}$} & \multirow{2}{*}{$\begin{array}{c}\text { Beam } \\
28 \\
\text { Days }\end{array}$} \\
\hline & & $\begin{array}{c}3 \\
\text { Days }\end{array}$ & $\begin{array}{c}7 \\
\text { Days }\end{array}$ & $\begin{array}{c}28 \\
\text { Days }\end{array}$ & & \\
\hline 1 & $0 \%$ & 6 & 6 & 6 & 6 & 6 \\
\hline 2 & $10 \%$ & 6 & 6 & 6 & 6 & 6 \\
\hline 3 & $20 \%$ & 6 & 6 & 6 & 6 & 6 \\
\hline 4 & $30 \%$ & 6 & 6 & 6 & 6 & 6 \\
\hline 5 & $40 \%$ & 6 & 6 & 6 & 6 & 6 \\
\hline \multicolumn{2}{|c|}{ Total } & \multicolumn{3}{|c|}{ Cubes $=90$} & $\begin{array}{l}\text { Cylinders } \\
=30\end{array}$ & $\begin{array}{l}\text { Beams } \\
=30\end{array}$ \\
\hline
\end{tabular}

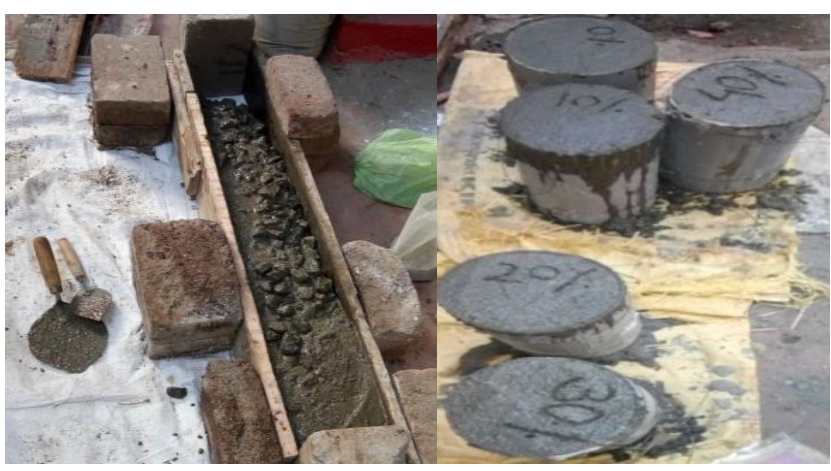

Fig.2: Casting of specimen

Published By:

Blue Eyes Intelligence Engineering and Sciences Publication

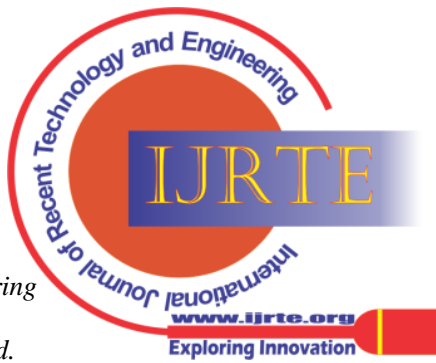




\section{TEST RESULTS}

Different tests were conducted on concrete. The $150 \mathrm{~mm}$ size cubes were tested for compressive strength test. The split tensile test was carried out on cylinders of $300 \mathrm{~mm}$ height and $150 \mathrm{~mm}$ diameter. The flexural strength test was performed on beams of size $150 \mathrm{~mm}$ x $150 \mathrm{~mm} \times 1000 \mathrm{~mm}$. The experimental results for various tests are mentioned below.

\section{A. Compressive Strength Test}

The compressive strength test was done on standard cubes for all five groups in two cases which are with and without hydrated lime as per IS: 516-1959. The concrete cubes are tested as shown in Fig. 3. These tests were conducted at 3 days, 7 days and 28 days of curing. The observations of experimental program are shown in Table - III and Table IV. Fig. 4, 6 and 8 are indicating the graphical comparison of cube compression test, split tensile strength and flexural strength test with and without hydrated lime after 28 days respectively. With the addition of clay with or without lime, all strengths are significantly decreased. Still there in no huge difference between $0 \%$ and $10 \%$ replacement results. It indicate that up $10 \%$ cement can be replaced by clay.

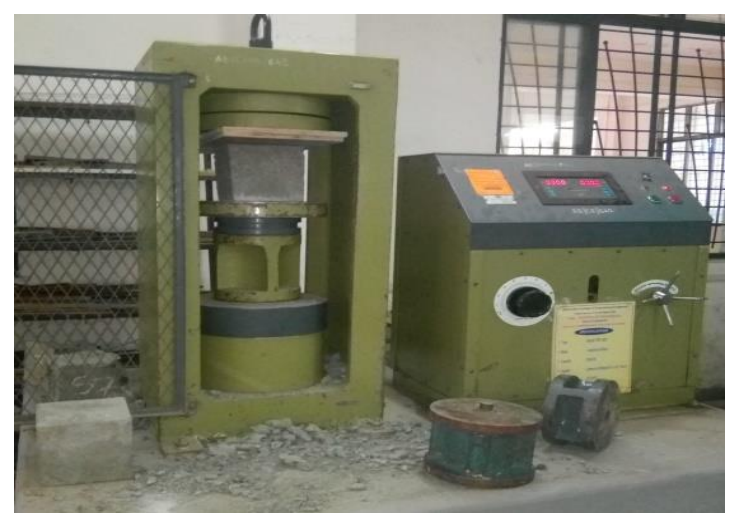

Fig. 3: Compression test

\section{Case I: Without hydrated lime}

Table- III: Compressive strength test result without hydrated lime

\begin{tabular}{|c|c|c|c|c|}
\hline $\begin{array}{c}\text { Cement } \\
\text { Replacement }\end{array}$ & Sr. No. & $\begin{array}{c}3 \text { days } \\
\text { Comp. Strength (MPa) }\end{array}$ & $\begin{array}{c}7 \text { days } \\
\text { Comp. Strength (MPa) }\end{array}$ & $\begin{array}{c}28 \text { days } \\
\text { Comp. Strength (MPa) }\end{array}$ \\
\hline \multirow{4}{*}{$0 \%$} & 1 & 12.84 & 18.53 & 26.58 \\
\hline & 2 & 12.67 & 17.69 & 26.75 \\
\hline & 3 & 12.48 & 17.78 & 26.53 \\
\hline & Avg. & 12.66 & 18.00 & 26.62 \\
\hline \multirow{4}{*}{$10 \%$} & 1 & 10.84 & 17.69 & 25.29 \\
\hline & 2 & 11.16 & 17.38 & 25.02 \\
\hline & 3 & 10.93 & 17.60 & 24.80 \\
\hline & Avg. & 10.98 & 17.55 & 25.04 \\
\hline \multirow{4}{*}{$20 \%$} & 1 & 8.04 & 15.82 & 23.82 \\
\hline & 2 & 7.82 & 15.51 & 23.56 \\
\hline & 3 & 7.96 & 15.64 & 23.64 \\
\hline & Avg. & 7.96 & 15.66 & 23.67 \\
\hline \multirow{4}{*}{$30 \%$} & 1 & 6.49 & 12.62 & 22.84 \\
\hline & 2 & 6.27 & 13.11 & 23.20 \\
\hline & 3 & 6.00 & 12.93 & 23.02 \\
\hline & Avg. & 6.25 & 12.89 & 23.02 \\
\hline \multirow{4}{*}{$40 \%$} & 1 & 5.87 & 10.67 & 20.98 \\
\hline & 2 & 6.13 & 10.36 & 21.13 \\
\hline & 3 & 5.42 & 10.89 & 20.71 \\
\hline & Avg. & 5.81 & 10.64 & 20.94 \\
\hline
\end{tabular}

\section{Case II: With hydrated lime}

Table- IV: Compressive strength test result with hydrated lime

\begin{tabular}{|c|c|c|c|c|}
\hline $\begin{array}{c}\text { Cement } \\
\text { Replacement }\end{array}$ & Sr. No. & $\begin{array}{c}\text { 3 days } \\
\text { Comp. Strength (MPa) }\end{array}$ & $\begin{array}{c}\text { 7 days } \\
\text { Comp. Strength (MPa) }\end{array}$ & $\begin{array}{c}\text { 28 days } \\
\text { Comp. Strength (MPa) }\end{array}$ \\
\hline \multirow{4}{*}{$0 \%$} & 1 & 12.80 & 17.87 & 27.20 \\
\cline { 2 - 5 } & 2 & 13.16 & 18.76 & 27.82 \\
\cline { 2 - 5 } & 3 & 13.50 & 18.58 & 28.62 \\
\cline { 2 - 5 } & Avg. & 13.15 & 18.40 & 27.88 \\
\hline \multirow{4}{*}{$10 \%$} & 1 & 11.47 & 17.96 & 26.00 \\
\cline { 2 - 5 } & 2 & 11.67 & 17.60 & 25.95 \\
\cline { 2 - 5 } & 3 & 11.29 & 17.78 & 26.09 \\
\hline \multirow{5}{*}{$20 \%$} & Avg. & 11.48 & 17.78 & 24.67 \\
\cline { 2 - 5 } & 2 & 9.24 & 16.53 & 24.62 \\
\cline { 2 - 5 } & 3 & 8.71 & 16.80 & 24.89 \\
\cline { 2 - 5 } & Avg. & 8.44 & 15.73 & 24.73 \\
\hline
\end{tabular}

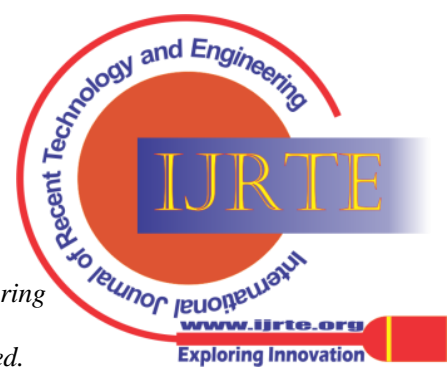




\begin{tabular}{|c|c|c|c|c|}
\hline \multirow{3}{*}{$30 \%$} & 1 & 6.76 & 13.15 & 23.77 \\
\cline { 2 - 5 } & 2 & 7.47 & 13.42 & 23.68 \\
\cline { 2 - 5 } & 3 & 6.31 & 13.51 & 23.91 \\
\cline { 2 - 5 } & Avg. & 6.85 & 13.36 & 21.69 \\
\cline { 2 - 5 } & 1 & 5.91 & 11.29 & 20.80 \\
\cline { 2 - 5 } & 2 & 6.22 & 12.36 & 22.32 \\
\cline { 2 - 5 } & 3 & 6.04 & 11.82 & 21.60 \\
\hline
\end{tabular}

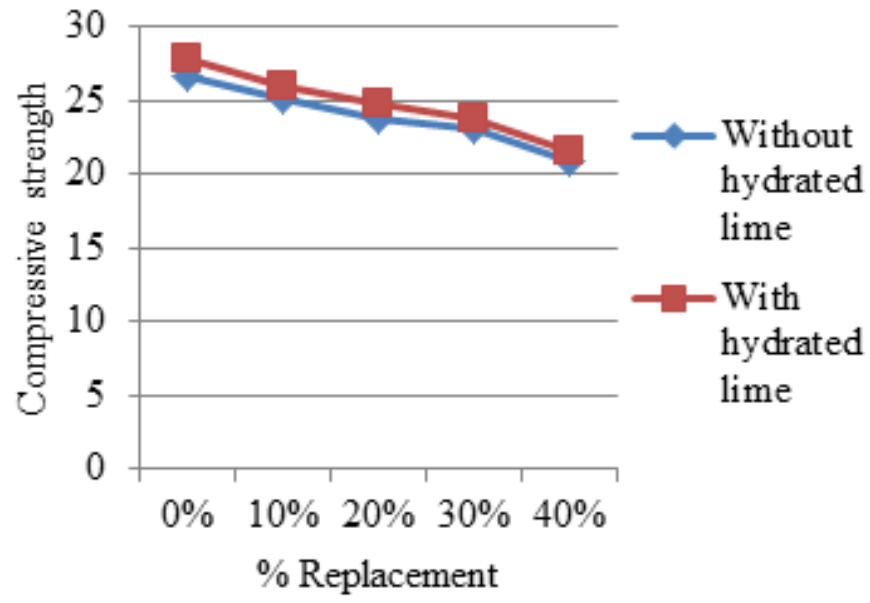

Fig. 4: Compressive strength of concrete without and with hydrated lime

\section{B. Split tensile strength test}

The failure of a cylindrical specimen is checked in a split tensile strength test. The test is taken on the cylinder by splitting along its middle plane parallel to the edges. The load is applied to opposite edges as per IS: $516-1959$. Fig. 5 shows the split tensile strength of the cylinder. Test results are given in Table - V and Table - VI. Formulation of Split tensile strength is as follows,

$$
\mathrm{f}_{t}=\frac{2 P}{\pi D L}
$$

Where,

$\mathrm{f}_{t}=$ Spilt tensile strength $\left(\mathrm{N} / \mathrm{mm}^{2}\right)$,

$\mathrm{P}=$ Load at failure $(\mathrm{N})$,

$\mathrm{L}=$ Length of Cylinder (mm),

$\mathrm{D}=$ Diameter of a cylinder $(\mathrm{mm})$.

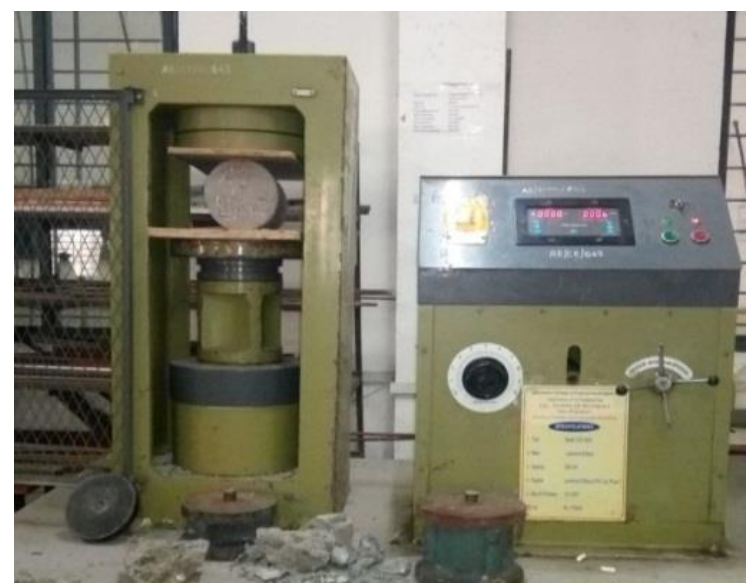

Fig. 5: Spilt tensile test

\subsubsection{Case I: Without hydrated lime}

Table- V: Split tensile strength results without hydrated lime

\begin{tabular}{|c|c|c|c|c|c|}
\hline $\begin{array}{c}\text { Sr. } \\
\text { No } \\
.\end{array}$ & $\begin{array}{c}\text { Replaceme } \\
\text { nt }\end{array}$ & $\begin{array}{c}\text { Specime } \\
\mathbf{n ~ 1}\end{array}$ & $\begin{array}{c}\text { Specime } \\
\mathbf{n ~ 2}\end{array}$ & $\begin{array}{c}\text { Specime } \\
\mathbf{n ~ 3}\end{array}$ & $\begin{array}{c}\text { Averag } \\
\mathbf{e}\end{array}$ \\
\hline 1 & $0 \%$ & 2.69 & 2.73 & 2.75 & 2.72 \\
\hline 2 & $10 \%$ & 2.60 & 2.63 & 2.59 & 2.61 \\
\hline 3 & $20 \%$ & 2.34 & 2.27 & 2.38 & 2.33 \\
\hline 4 & $30 \%$ & 2.27 & 2.21 & 2.30 & 2.26 \\
\hline 5 & $40 \%$ & 2.08 & 2.17 & 2.03 & 2.07 \\
\hline
\end{tabular}

\subsubsection{Case II: With hydrated lime}

Table- VI: Split tensile strength results with hydrated lime

\begin{tabular}{|c|c|c|c|c|c|}
\hline $\begin{array}{c}\text { Sr. } \\
\text { No } \\
.\end{array}$ & $\begin{array}{c}\text { Replaceme } \\
\text { nt }\end{array}$ & $\begin{array}{c}\text { Specime } \\
\mathbf{n ~ 1}\end{array}$ & $\begin{array}{c}\text { Specime } \\
\mathbf{n ~ 2}\end{array}$ & $\begin{array}{c}\text { Specime } \\
\mathbf{n ~ 3}\end{array}$ & $\begin{array}{c}\text { Averag } \\
\mathbf{e}\end{array}$ \\
\hline 1 & $0 \%$ & 3.05 & 3.03 & 2.97 & 3.02 \\
\hline 2 & $10 \%$ & 2.87 & 2.89 & 2.86 & 2.87 \\
\hline 3 & $20 \%$ & 2.53 & 2.62 & 2.57 & 2.57 \\
\hline 4 & $30 \%$ & 2.36 & 2.31 & 2.40 & 2.36 \\
\hline 5 & $40 \%$ & 2.17 & 2.20 & 2.15 & 2.17 \\
\hline
\end{tabular}

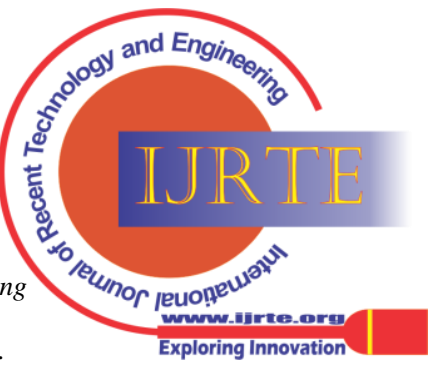




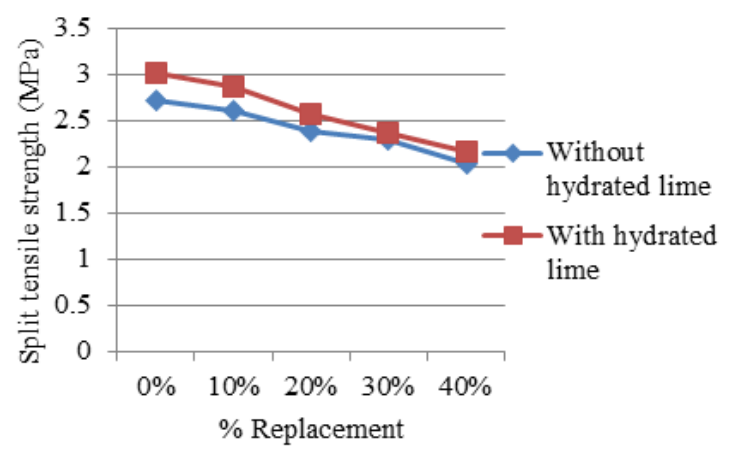

Fig. 6: Split tensile strength of concrete without and with hydrated lime

\section{Flexural strength test}

The beams were tested for 28 days strength. The central point load is applied on the specimen. Fig. 7 shows the experimental setup for flexural strength test. The test results are given in Table - VII and Table - VIII for without and with hydrated lime respectively. With the increasing percentage of clay, the flexural strength is getting reduced in both the cases. The flexural strength is determined by the following formula,

$$
\mathrm{f}_{b t}=\frac{3 P L}{2 b d^{2}}
$$

Where,

$\mathrm{f}_{b t}=$ Flexural strength (MPa),

$\mathrm{P}=$ Load at failure $(\mathrm{N})$,

$\mathrm{L}=$ Span of specimen $(\mathrm{mm})$,

$\mathrm{b}=$ Width of specimen $(\mathrm{mm})$,

$\mathrm{d}=$ Depth of specimen $(\mathrm{mm})$.

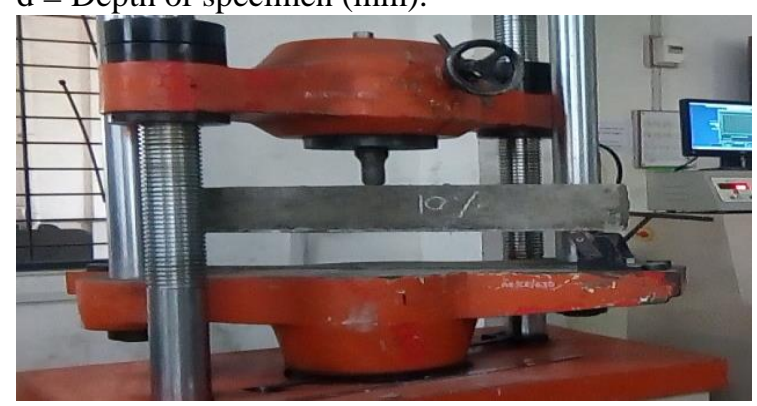

Fig.7: Flexural strength test

\section{Case I: Without hydrated lime}

Table- VII: Flexural strength results without hydrated lime

\begin{tabular}{|c|c|c|c|c|c|}
\hline $\begin{array}{c}\text { Sr. } \\
\text { No. }\end{array}$ & Replacement & $\begin{array}{c}\text { Specimen } \\
\mathbf{1}\end{array}$ & $\begin{array}{c}\text { Specimen } \\
\mathbf{2}\end{array}$ & $\begin{array}{c}\text { Specimen } \\
\mathbf{3}\end{array}$ & Average \\
\hline 1 & $0 \%$ & 3.07 & 3.12 & 2.95 & 3.05 \\
\hline 2 & $10 \%$ & 2.90 & 2.93 & 2.97 & 2.93 \\
\hline 3 & $20 \%$ & 2.77 & 2.83 & 2.81 & 2.80 \\
\hline 4 & $30 \%$ & 2.64 & 2.71 & 2.69 & 2.68 \\
\hline 5 & $40 \%$ & 2.38 & 2.41 & 2.39 & 2.39 \\
\hline
\end{tabular}

\section{Case II: With hydrated lime}

Table- VIII: Flexural strength results with hydrated lime

\begin{tabular}{|c|c|c|c|c|c|}
\hline $\begin{array}{c}\text { Sr. } \\
\text { No. }\end{array}$ & Replacement & $\begin{array}{c}\text { Specimen } \\
\mathbf{1}\end{array}$ & $\begin{array}{c}\text { Specimen } \\
\mathbf{2}\end{array}$ & $\begin{array}{c}\text { Specimen } \\
\mathbf{3}\end{array}$ & Average \\
\hline 1 & $0 \%$ & 3.29 & 3.21 & 3.34 & 3.28 \\
\hline 2 & $10 \%$ & 3.08 & 3.05 & 3.09 & 3.07 \\
\hline 3 & $20 \%$ & 2.88 & 2.91 & 2.92 & 2.93 \\
\hline 4 & $30 \%$ & 2.79 & 2.83 & 2.86 & 2.83 \\
\hline 5 & $40 \%$ & 2.47 & 2.52. & 2.54 & 2.51 \\
\hline
\end{tabular}

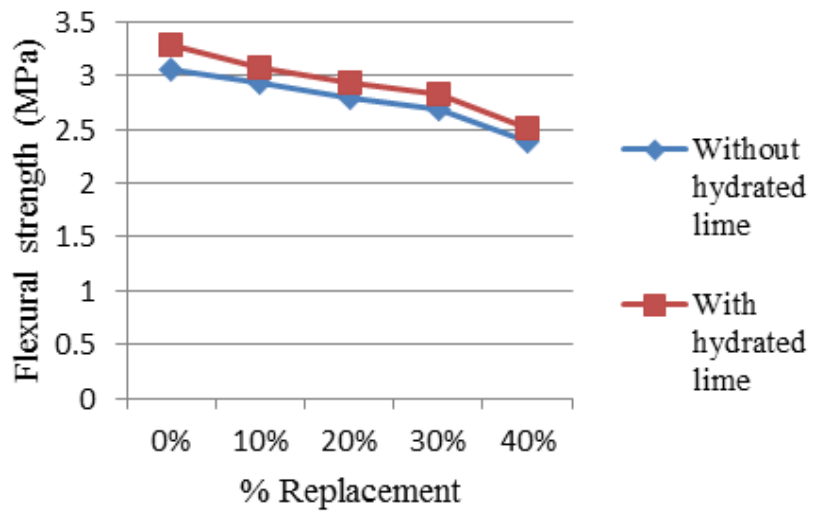

Fig. 8: Flexural strength of concrete without and with hydrated lime

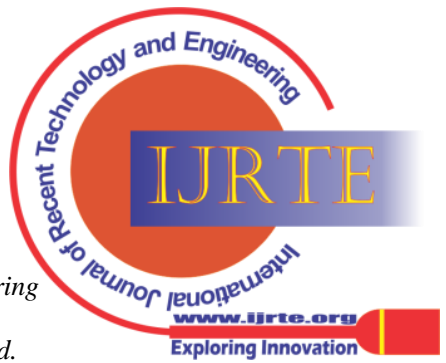




\section{CONCLUSIONS}

After varying the percentage of clay as a replacement to cement with and without hydrated lime following conclusions are made,

1) With the rise in the percentage of clay, the strength of specimens getting decreased. In case of hydrated lime, significant improvement in strength is found compared to the case of without hydrated lime

2) Clay can be modified slightly by adding industry-produced lime to form concrete.

3) The strength of concrete in compression is decreased around $5 \%$ to $6 \%$ with an increase in the percentage of clay in both the cases such as with and without hydrated lime.

4) For $0 \%$ replacement of clay, concrete strength of with hydrated lime is $4.5 \%$ more compared to without hydrated lime. When $10 \%$ cement is replaced by clay, the hydrated lime improves the compressive strength up to $3.73 \%$ when compared to without hydrated lime.

5) In split tensile strength, about 9.9\% increase in strength is seen for $0 \%$ cement replacement with hydrated lime. With the increase in the percentage of clay, a gradual loss in split tensile strength is found.

6) For the flexural strength test, there is a reduction in the strength of concrete with a rise in the percentage of clay. When compared to without hydrated lime case up to $4 \%$ to $8 \%$ increase in flexural strength is noticed using hydrated lime.

7) For $10 \%$ replacement of clay with hydrated lime gives satisfactory results for compressive strength test, split tensile strength test as well as flexural strength test.

\section{REFERENCES}

1. F. R. Arooz, and R. U. Halwatura, "Mud-concrete block (MCB): mix design \& durability characteristics," Case Studies in Construction Materials, vol.8, 2018, pp. 39-50.

2. M. Bediako, S. K. Y. Gawu, A. A. Adjaottor, and J. S. Ankrah, "Early and late strength characterization of portland cement containing calcined low-grade kaolin clay," Journal of Engineering, 2016, pp. 1-5.

3. T. Danner, G. Norden, and H. Justnes, "Characterisation of calcined raw clays suitable as supplementary cementitious materials," Applied Clay Science, vol. 162, 2018, pp. 391-402.

4. A. Ekinci, M. Hanafi, and E. Aydin, "Strength, stiffness, and microstructure of wood-ash stabilized marine clay," Minerals, vol. 10, no. 9, 2020, pp. 1-23.

5. V. Ellappan, V. Amudhan, E. Prathik, and A. Ebenezer Stephen, "Experimental investigation on partial replacement of cement with marble powder," International Journal of Civil Engineering and Technology, vol. 9, no. 5, 2018, pp. 741-750.

6. Y. Fan, S. Zhang, S. Kawashima and S. P. Shah, "Influence of kaolinite clay on the chloride diffusion property of cement-based materials," Cement and Concrete Composites, vol. 45, 2014, pp. 117-124.

7. S. Hamidi, and S. M. Marandi, "Effect of clay mineral types on the strength and microstructure properties of soft clay soils stabilized by epoxy resin," Geomechanics and Engineering, vol. 15, no. 2, 2018, pp. 729-738.

8. P. Jamsawang, H. Poorahong, N. Yoobanpot, S. Songpiriyakij and P. Jongpradist, "Improvement of soft clay with cement and bagasse ash waste," Construction and Building Materials, vol. 154, 2017, pp. 61-71.

9. R. Jaskulski, D. Jóźwiak-Niedźwiedzka, and Y. Yakymechko, "Calcined clay as supplementary cementitious material," Materials, vol. 13, no. 21, 2020, pp. 1-36.

10. Noor-Ul-Amin, "Use of clay as a cement replacement in mortar and its chemical activation to reduce the cost and emission of greenhouse gases," Construction and Building Materials, vol. 34, (2012), pp. 381-384.

11. M. Oduor Otieno, C. K. Kabubo, and Z. Abiero Gariy, "A Study of Uncalcined Termite Clay Soil as Partial Replacement in Cement as a
Sustainable Material for Roofing Tiles in Low Cost Housing Schemes in Kenya," International Journal of Engineering and Advanced Technology, vol. 3, 2015, pp. 2249-8958.

12. G. V. K. Reddy, V. R. Rao, and M. A. Kumar Reddy, "Experimental investigation of strength parameters of cement and concrete by partial replacement of cement with Indian calcium bentonite," International Journal of Civil Engineering and Technology, vol. 8, no. 1, 2017, pp. 512-518.

13. V. Sahu, and V. Gayathri, "The Use of Fly Ash and Lime Sludge as Partial Replacement of Cement in Mortar," International Journal of Engineering and Technology Innovation, vol. 4, no. 1, 2014, pp. 30-37.

14. E. R. Sujatha, and S. Selsia Devi, "Reinforced soil blocks: Viable option for low cost building units," Construction and Building Materials, vol. 189, 2018, pp. 1124-1133.

15. C. Udawattha, and R. Halwatura, "Embodied energy of mud concrete block (MCB) versus brick and cement blocks," Energy and Buildings, vol. 126, 2016, pp. 28-35.

\section{AUTHORS PROFILE}

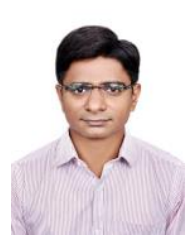

Dr. Sachin Balkrishna Kandekar, B.E. Civil, M.E. Structures, Ph.D. Civil Engineering, Working as an Associate Professor at Amrutvahini College of Engineering, Sangamner, Savitribai Phule Pune University, Author has published 18 papers in international journals and 6 papers in international conferences, Worked on two research projects and 5 consultancy projects,

ISTE. Author is having lifetime membership of IEI, (India) and

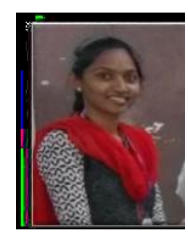

Ms. Swati Karbhari Wakchaure, B.E. Civil and Postgraduate student at Amrutvahini College of Engineering, Sangamner, Savitribai Phule Pune University.
Published By:

Blue Eyes Intelligence Engineering

and Sciences Publication

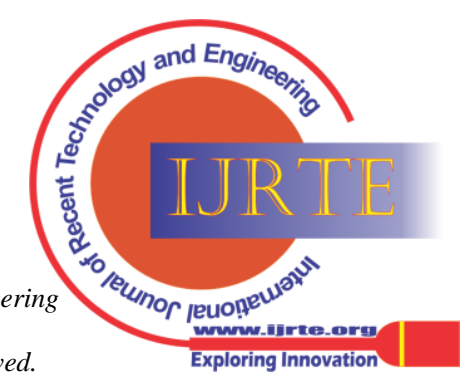

